from the developing countries of West Africa as well as to those from other parts of the world who wish to carry out research in the field of development.

Further information can be obtained from the Director, Centre for Developing-Area Studies, McGill University, Montreal 2, P.Q., Canada.

\title{
The Development of African Studies in Italy
}

Following the tradition of African studies established in Italy by such scholars as Ignazio Guidi, Carlo Conti Rossini, and Enrico Cerulli, particularly in regard to those countries with which Italy has had continuous political, economic, and cultural relations, three Chairs of the History and Institutions of the Afro-Asian countries have been recently created within the Faculties of Political Science of the Universities of Rome, Perugia, Cagliari, and Pavia, replacing in the last of these a Chair of Colonial History and Policy, held for many years by Professor Carlo Giglio. A Chair of Ethiopian Language and Literature (Amharic) has also been created as part of the University Institute of Oriental Studies in Naples.

Professor Guiseppe Vedovato, formerly Professor of the History of Treaties and International Policy at the University of Perugia, and Vice-President of the Commission on Foreign Policy of the Lower Chamber of the Italian Parliament, has been appointed to the chair in Rome. The chair at Perugia is held by Professor Giuseppe A. Costanzo-Beccaria, for many years Professor of Indigenous Law and Dean of the University Institute of Somalia, and that at Cagliari by Professor Enrico de Leone, formerly Professor of Colonial History and Policy. Professor Lanfranco Ricci, on the staff of the School of Oriental Studies at the University of Rome, will occupy the chair at the University Institute of Oriental Studies in Naples.

It is the intention to co-ordinate African studies in the historical, political, and legal fields, with those of a more general nature. Attention will be given to problems relating to political, economic, and cultural co-operation between Africa and Europe. It is also hoped to continue publication, under the auspices of the Ministry for Foreign Affairs, of an extensive and well-documented history of Italian colonization, several volumes of which have already appeared.

A valuable contribution to the development of African studies in Italy has been made by the Italian Institute for Africa, under its President, the Hon. Salvatore Foderaro.

\section{African Studies at the University of Warsan}

ThE Centre of African Studies at the University of Warsaw, directed by Professor Stefan Strelcyn, was established in 1962. Specialists in the field of African Studies are in close co-operation with the Centre while remaining associated with their respective university departments. The Centre plans programmes and grants scholarships to graduates preparing doctoral theses in any branch of African studies. Specialized lectures on African problems are delivered at the Institute of Oriental Studies (African philology) and at the course in African Problems (general instruction at postgraduate level). Information about Africa has been included in the teaching curricula of various university departments, and includes ethnography, human geography, sociology, and social anthropology, political science, economics, law, religions, history and prehistory, fine arts, literature and languages (notably Arabic, Egyptian and Coptic, Ethiopic (Ge'ez and Amharic), Hausa, Swahili, Ewe, and Bambara. The Centre also arranges seminars on special topics; the first, on 24 and 25 January 1965, dealt with the problems of state and law in Africa. The Africana Bulletin appears twice a yearl and the Centre has its own specialized library. Work is proceeding on

\footnotetext{
I See Africa, xxxv, Jan. 1965, Ior.
} 